\title{
Analisis Determinan Penghindaran Pajak pada Perusahaan Publik yang Dikontrol Keluarga
}

\author{
Sabar Warsini ${ }^{\mathrm{a},{ }^{*}}$ and Hayati Fatimah ${ }^{\mathrm{b}}$ \\ a Politeknik Negeri jakarta, sabar.warsini@akuntansi.pnj.ac.id, Indonesia \\ ${ }^{\mathrm{b}}$ Politeknik Negeri jakarta,-, Indonesia
}

\begin{abstract}
This study aims to explore the determination of tax avoidance in family-controlled public companies. The research sample was 336 firm years of public companies listed on the Indonesia Stock Exchange. Hypothesis testing uses multivariate regression analysis. This study found that tax avoidance is influenced by the characteristics of the company and corporate governance mechanisms. We prove that leverage has a negative effect on tax avoidance, company size does not significantly influence tax avoidance, pretax return on asset and the level of financial distress have a positive effect on tax avoidance. This study also found that auditor quality has a negative effect on tax avoidance, while management compensation has a positive effect. However, this study cannot prove the effect of the effectiveness of the independent board on tax avoidance.
\end{abstract}

Keywords: tax avoidance, family-controlled public company, company's characteristic, corporate governance mechanism

*Corresponding author. E-mail: sabar.warsini@akuntansi.pnj.ac.id 


\section{Pendahuluan}

Beban pajak merupakan beban yang sangat signifikan bagi suatu perusahaan. Dengan diterapkannya tarif pajak penghasilan perusahaan (PPh Badan) sebesar 25\% dapat diartikan bahwa perusahaan harus menyerahkan seperempat dari laba yang diperoleh kepada pemerintah. Tarif PPh Badan sebesar $25 \%$ yang berlaku di Indonesia ini merupakan tarif pajak yang lebih tinggi dibandingkan dengan tarif pajak PPh Badan yang diterapkan di negara lain seperti: Singapura memberlakukan tarif pajak korporasi $17 \%$, Brunai Darusalam 18\%, Thailand, Kamboja, dan Vietnam sebesar 20\%, Malaysia 24\% dan Hong Kong 16,5\% (The Global Competitiveness Report, 2017).

Tingginya tarif pajak korporasi menjadi salah satu faktor yang mendorong wajib pajak untuk menghindari pajak (Becker, Jacob dan Jacob, 2013). Selain tarif pajak yang tinggi, ketika membayar pajak ke kas negara wajib pajak tidak memperoleh imbalan atau kompensasi secara langsung yang diterima, hal ini juga dapat mendorong keengganan wajib pajak untuk membayar pajak.

Penghindaran pajak (tax avoidance) tidak sematamata dipengaruhi oleh tingginya tarif pajak dan faktor kompensasi. Penelitian yang sudah ada telah membuktikan bahwa penghindaran pajak dipengaruhi oleh beberapa faktor seperti: skala perusahaan (Hanlon, Krishnan dan Mills, 2012; Dharmapala dan Riedel, 2013), tingkat pengembalian investasi sebelum pajak (Frank, Luann, Lynch, dan Rego.2009), financial distress (Mills dan Newberry, 2001), foreign income (Dyreng, Hanlon, dan Maydew, 2010; Dharmapala dan Riedel, 2013), tingkat leverage perusahaan (Koh, Park dan Han, 2011; Moore, 2012), dan penghindaran pajak juga dipengaruhi oleh tata kelola perusahaan/corporate governance (Atwood, Drake, Myer dan Myer, 2012; Richardson, Lanis, dan Leung, 2014; Khan, Srinivasan dan Tan, 2016)

Penelitian mengenai faktor-faktor penghindaran pajak seperti tersebut diatas dilakukan di negara maju seperti di US, Australia dan negara negara Eropa, dimana perusahaan publik di negara maju mempunyai karakteristik kepemilikan saham yang menyebar, hampir tidak ada dominasi kepemilikan. Masih sangat terbatas penelitian penghindaran pajak yang mempertimbangkan karakteristik struktur kepemilikan perusahaan.

Seperti kita ketahui bahwa struktur kepemilikan perusahaan publik di negara-negara Asia pada umumnya dan khususnya di Indonesia mempunyai karakteristik yang unik yaitu struktur kepemilikan perusahaan publik terkonsentrasi dengan dominasi kepemilikan keluarga. Hasil penelitian menunjukkan bahwa lebih dari 50\% perusahaan publik di Indonesia didominasi oleh kepemilikan keluarga (Claessen, Dajnkov, dan Lang, 2000; Hanazaki dan Liu, 2007), dan karateristik ini masih konsisten hingga saat ini seperti temuan Warsini (2018) bahwa kepemilikan keluarga pada perusahaan publik di Indonesia berkisar $28 \%$ hingga $72 \%$. Oleh karena itu sangat penting dilakukan suatu penelitian untuk menginvestigasi faktor determinan penghindaran pajak pada perusahaan publik yang dikontrol keluarga. Apakah faktor yang secara umum merupakan determinan penghindaran pajak pada perusahaan public dengan kepemilikan menyebar juga berlaku pada perusahaan publik yang dikontrol oleh keluarga. Pertanyaan ini muncul mengingat kuatnya kendali kepemilikan keluarga bisa jadi akan sangat mempengaruhi kebijakan manajemen perusahaan termasuk kebijakan penghindaran pajak.

Penelitian ini bertujuan untuk mengeksplorasi faktor yang menentukan penghindaran pajak pada perusahaan public yang dikontrol keluarga yang terdaftar di Bursa Efek Indonesia. Berbeda dengan penelitian yang sudah ada, dimana determinan penghindaran pajak lebih ditekankan pada faktor karakteristik perusahaan seperti: ukuran perusahaan, tingkat profitabilitas, tingkat leverage, dan financial distress. Penelitian ini mempertimbangkan faktor tata kelola perusahaan (corporate governance) sebagai determinan penghindaran pajak, dengan alasan bahwa penghindaran pajak merupakan kebijakan dan keputusan manajemen yang bisa membawa dampak positif (penghematan) maupun dampak negative (oportunistik), maka baik buruknya tata kelola perusahaan tentu saja sangat mempengaruhi kebijakan manajemen tersebut.

Hasil penelitian ini diharapkan dapat memberikan kontribusi baik dalam pengembangan penelitian di bidang perpajakan maupun kontribusi praktis. Secara teoritis hasil penelitian ini mengembangkan penelitian yang menginvestaigasi determinan penghindaran pajak yang sudah ada dengan menambahkan faktor corporate governance, dan memperkaya literature penghindaran pajak pada perusahaan public yang dikontrol keluarga. Sedangkan secara praktis hasil penelitian ini akan memberikan masukan bagi investor dan regulator khususnya regulator di bidang pajak akan adanya tindakan penghindaran pajak pada perusahaan public. 


\section{Kajian Literatur dan Pengembangan Hipotesis}

\section{Penghindaran Pajak}

Secara umum penghindaran pajak merupakan berbagai upaya yang dilakukan oleh wajib pajak untuk membayar pajak serendah mungkin. Darussalam, Hutagaol dan Septriadi (2010) menyatakan bahwa penghindaran pajak (tax avoidance) bisa dilakukan oleh wajib pajak melalui skema: (1) penghindaran pajak yang tidak melanggar undang-undang (acceptable tax avoidance) dan (2) penghindaran pajak yang melanggar undang-undang (unacceptable tax avoidance) yang juga sering disebut sebagai tax evasion. Kedua skema penghindaran pajak tersebut berpotensi merugikan penerimaan negara.

Berbagai penelitian penghindaran pajak mendefinisikan penghindaran pajak yang berbedabeda. Dyreng, Hanlon dan Maydew (2010) mendefinisikan penghindaran pajak sebagai semua pengaturan transaksi yang mengurangi pajak perusahaan relative terhadap laba akuntansi sebelum pajak. Lim (2011) mendefinisikan tax avoidance sebagai penghematan pajak yang timbul dengan memanfaatkan kelemahan (loopholes) peraturan pajak yang dilakukan secara legal untuk meminimumkan jumlah pajak yang dibayar. Sedangkan Taylor dan Richardson (2013) menyebutkan penghindaran pajak adalah upaya penurunan jumlah penghasilan kena pajak oleh manajer perusahaan melalui perencanaan pajak dengan cara yang legal, memanfaatkan grey area sampai dengan cara yang illegal.

\section{Penghindaran Pajak pada Perusahaan Publik yang Dikontrol Keluarga}

Bena dan Hanaousek (2008) membedakan struktur kepemilikan saham perusahaan menjadi dua yakni: pemegang saham mayoritas (kepemilikan lebih dari 50\%) dan kepemilikan minoritas (kepemilikan tidak melebihi 50\%). Terdapat dua pandangan yang berbeda mengenai hadirnya kepemilikan keluarga menjadi pengendali perusahaan publik yaitu:

(1). pandangan alignment, menyatakan bahwa kepemilikan keluarga membawa dampak positif bagi operasi perusahaan karena adanya keselarasan kepentingan antara manajemen dengan pemilik sehingga semakin besar kepemilikan keluarga tidak mendorong adanya perilaku tax avoidance (Chen, Chen, Cheng dan Shevlin, 2010; Koh, Park, dan Han,
2011). Sebagai pemilik mayoritas, keluarga lebih berorientasi pada reputasi, profesionalisme, dan keberlanjutan perusahaan dalam jangka panjang.

(2). pandangan entrenchment, menyatakan bahwa hadirnya kepemilikan keluarga sebagai pengendali perusahaan cenderung memasukan anggota keluarganya sebagai manajemen perusahaan sehingga dapat bersepakat dengan manajemen untuk menjalankan kebijakan yang hanya menguntungkan keluarga sehingga kepentingan pemegang saham minoritas terabaikan (Jiang, Habib, dan Hu, 2011). Menurut pandangan entrenchment perusahaan keluarga cenderung melakukan penghindaran pajak karena sebagai mayoritas mereka akan menikmati keuntungan yang paling besar.

Hasil penelitian terdahulu menemukan bahwa perilaku tax avoidance lebih rendah pada perusahaan yang dikontrol oleh keluarga (Chen, Chen, Cheng, dan Shevlin, 2010; Mafrolla dan D'Amico, 2016; Masripah, Diyanty, dan Fitriasari, 2017).

\section{Faktor Determinan Penghindaran Pajak}

Terdapat banyak faktor yang menjadi pendorong perilaku penghindaran pajak. Faktor determinan ini berdasarkan pada teori yang relevan dengan tax avoidance. Dari perspektif teori struktur modal, penghindaran pajak sangat dipengaruhi oleh struktur permodalan perusahaan. Ross, Westerfield, dan Jordan (2008) menyatakan bahwa perusahaan yang menggunakan sumber dana dari utang akan memperoleh penghematan pajak atas pembayaran beban bunga utang. Mengacu pada teori struktur modal maka perilaku penghindaran pajak dipengaruhi oleh tingkat penggunaan utang (leverage) perusahaan. Penelitian terdahulu telah membuktikan bahwa perilaku penghindaran pajak lebih rendah pada perusahaan dengan tingkat leverage yang lebih tinggi (Gaham dan Tucker, 2006; Koh, Park dan Han, 2011; Moore, 2012). Berdasarkan teori struktur modal, hipotesis pertama yang dikembangkan dalam penelitian ini adalah:

H1 Semakin besar tingkat leverage perusahaan semakin rendah penghindaran pajak

Dalam teori perusahaan (theory of the firm) menyatakan bahwa perusahaan adalah organisasi yang menggabungkan dan mengorganisasikan seluruh sumber dya yang dimiliki untuk menghasilkan barang/jasa untuk dijual. Political cost hypothesis (Scott, 2014) menyatakan bahwa 
informasi perusahaan besar biasanya lebih mudah diakses oleh investor sehingga informasi laba menjadi hal yang pentig untuk dicermati. Dikaitkan dengan tingkat kepatuhan pajak Hanlon, Mills dan Slemrod (2005) menemukan bahwa perusahaan besar cenderung mempunyai tingkat kepatuhan pajak yang lebih rendah. Sejalan dengan political cost hypothesis hasil penelitian di Indonesia (Parulian, 2014; Warsini, 2018) menemukan bahwa ukuran perusahaan berpengaruh negative terhadap penghindaran pajak. Dapat diartikan bahwa perusahaan yang besar (WP besar) cenderung menjadi sorotan masyarakat sehingga tidak terdorong untuk melakukan tindakan penghindaran pajak karena bagaimanapun penghindaran pajak adalah merugikan negara sehingga dapat membawa risiko reputasi jika tindakan penghindaran pajak terdeteksi oleh regulator pajak. Mengacu pada political cost hypothesis maka hipotesis kedua yang dikembangkan dalam penelitian ini adalah:

H2 Semakin besar ukuran perusahaan semakin rendah penghindaran pajak

Besarnya beban pajak yang harus dibayar oleh perusahaan sangat tergantung dari besarnya Penghasilan Kena Pajak (PKP). Penghasilan Kena Pajak atau laba fiscal dapat ditentukan dengan cara melakukan koreksi atas laba rugi komersial. Perusahaan dapat mengupayakan membayar pajak yang lebih rendah dengan memanfaatkan loopholes peraturan pajak tentang beban yang dapat dikurangkan (deductible expenses), kategori objek pajak, penerapan metode akuntansi dan pengaturan transaksi yang berkaitan dengan perlakuan pajak.

Semakin besar laba kena pajak, maka perusahaan akan membayar pajak yang lebih besar. Oleh karena itu semakin besar tingkat profitabilitas perusahaan akan mendorong manajemen untuk melakukan berbagai upaya guna membayar pajak yang lebih rendah. Sebaliknya perusahaan yang merugi cenderung tidak melakukan upaya penghindaran pajak dikarenakan sesuai dengan peraturan perpajakan (UU Pajak Penghasilan) perusahan yang merugi akan memperoleh kompensasi pembayaran pajak. Frank, Luann, Lynch dan Rego (2009) menemukan bahwa tingkat pengembalian investasi sebelum pajak berpengaruh positif terhadap pajak agresif. Hasil ini sejalan dengan Yin dan Cheng (2004) yang menyatakan bahwa perusahaan yang merugi tidak melakukan penghindaran pajak. Mengacu pada hasil penelitian terdahulu hipotesis ketiga yang dikembangkan dalam penelitian ini adalah:

H3 Semakin besar tingkat pengembalian investasi sebelum pajak semakin tinggi penghindaran pajak

Beban pajak merupakan aliran kas keluar yang harus dibayar oleh perusahaan kepada negara. Kapan wajib pajak harus membayar pajak sudah diatur didalam peraturan perundang-undangan perpajakan. Kepatuhan wajib pajak dalam menyetorkan beban pajak yang terutang sangat dipengaruhi oleh tersedia tidaknya kas yang ada dalam perusahaan. Perusahaan yang terindikasi mengalami kesulitan keuangan (financial distress) akan kesulitan untuk memenuhi kewajiban membayar pajak. Frank, Luann, Lynch dan Rego (2009) menyatakan bahwa financial distress merupakan faktor insentif bagi manajemen perusahaan untuk melakukan pengaturan laba fiscal. Warsini (2018) menemukan bahwa financial distress berpengaruh positif terhadap pelaporan pajak agresif. Mengacu pada hasil penelitian yang sudah ada maka hipotesis ke empat yang dikembangkan dalam penelitian ini adalah:

H4 Semakin tinggi financial distress perusahaan semakin tinggi penghindaran pajak

Keempat faktor tersebut diatas merupakan faktor yang menggambarkan karateristik perusahaan. Penghindaran pajak bukan hanya dipengaruhi oleh karateristik perusahaan tetapi tentu saja dipengaruhi oleh berbagai kepentingan yang tercermin dalam tata kelola perusahaan (corporate governance). Hingga saat ini studi yang mengeksplorasi pengaruh mekanisme corporate governance terhadap penghindaran pajak masih sangat terbatas

Garbarino (2007) menyatakan bahwa seperti halnya manajemen laba agresive, manajemen pajak agresive juga merupakan masalah agensi. Pandangan tradisional mengemukakan bahwa beban pajak yang rendah akan meningkatkan kekayaan pemegang saham, akan tetapi pandangan moderat menyatakan bahwa manajemen perusahaan merupakan pihak yang paling mengetahui kondisi perusahaan dan merupakan pihak yang diberi wewenang untuk mengatur alokasi sumber daya yang dimiliki perusahaan, sehingga apakah sebenarnya tindakan penghindaran pajak yang dilakukan manajemen ditujukan untuk menaikan kekayaan pemegang saham atau justru untuk memenuhi kepentinganya sendiri menjadi suatu permasahan tersendiri. 
Berkaitan dengan manajemen pajak, Desai dan Dharmapala (2009) menyatakan bahwa manajemen perusahaan melakukan kebijakan penghematan pajak bisa saja semata-mata untuk melaporkan laba yang lebih besar sehingga kompensasi yang diterima juga besar, namun pada kenyataannya penghematan pajak tersebut tidak berdampak pada kenaikan kemakmuran pemegang saham.

Berdasarkan perpekstif teori keagenan, tindakan penghindaran pajak dapat diminimalisir dengan adanya tata kelola perusahaan yang baik (good corporate governance). Tata kelola perusahaan yang baik dicerminkan dengan adanya fungsi pengawasan yang efektif yang direfleksikan oleh efektifnya pengawasan dewan komisarin independen, penggunaan auditor eksternal yang berkualitas, dan kompensasi manajemen.

Jaggi et al (2009) mengemukakan bahwa outside directors lebih independen terhadap manajemen dibandingkan inside directors sehingga lebih efektif dalam melakukan fungsi pengawasan terhadap manajemen perusahaan. Penelitian yang menguji pengaruh dewan komisaris independen terhadap penghindaran pajak masih sangat terbatas. Lanis dan Richardson (2011) melakukan pengujian pengaruh komposisi dewan direksi terhadap tax aggressiveness. Dengan menggunakan data perusahaan public di Australia menemukan bukti bahwa semakin besar proporsi outside directors menurunkan kemungkinan tax aggressiveness. Hasil ini tidak sejalan dengan Minnick dan Noga (2010) yang tidak dapat membuktikan adanya pengaruh dari karakteristik dewan komisaris terhadap manajemen pajak.

Berdasarkan pada fungsi pengawasan dewan komisaris independen maka hipotesis kelima yang dikembangkan dalam penelitian ini adalah:

H5 Semakin besar proporsi dewan komisaris independen semakin rendah penghindaran pajak

Dalam teori keagenan Jensen dan Meckling (1976) menyatakan bahwa audit eksternal merupakan salah satu mekanisme pengendalian untuk mengurangi masalah keagenan yang terjadi karena adanya kesenjangan informasi antara manajer dengan stakeholders lainnya. Dari perspektif laporan keuangan Maydew dan Shackelford (2006) menyatakan bahwa auditor eksternal memainkan peran dalam menentukan pengaruh aktifitas penghindaran pajak terhadap laporan keuangan.

Peran auditor eksternal dalam penghindaran pajak telah diuji oleh McGuire, Omer dan Wang (2012) yang menemukan bahwa auditor yang mempunyai tax expertise berpengaruh negatif terhadap penghindaran pajak. Penelitian lainnya dilakukan oleh Noh, Doocheol dan Guiran (2014), Kanagaretnam, Lee dan Lim (2016) secara konsisten menemukan bahwa perusahaan yang diaudit oleh auditor yang berkualitas yang diukur penguasaan pangsa pasar terbukti mampu menurnkan penghindaran pajak oleh perusahaan. Berdasarkan pada fungsi auditor eksternal dan hasil penelitian yang sudah ada maka hipotesis ke enam yang dikembangkan dalam penelitian ini adalah:

H6 Penghindaran pajak lebih rendah pada perusahaan yang diaudit oleh auditor eksternal yang berkualitas.

Corporate governance juga dicerminkan pada tinggi rendahnya kompensasi yang diterima oleh manajemen perusahaan. Besar kecilnya kompensasi yang diterima oleh manajemen dapat mengurangi masalah agensi yang terjadi antara manajemen dengan pemegang saham. Pada umumnya kompensasi manajemen diberikan berdasarkan perolehan laba yang dibukukan, oleh karena itu manajemen akan berusaha untuk melakukan berbagai upaya guna meningkatkan laba misalnya dengan menekan beban pajak. Hanlon, Mills dan Slemrod (2005) menemukan bahwa semakin besar kompensasi yang diterima oleh manajemn akan berpengaruh pada semakin besar upaya penghindaran pajak. Hasil tersebut konsisten dengan penelitian yang lebih baru oleh Gaertner (2014) yang menemukan bahwa kompensasi manajemen sesudah pajak berpengaruh positif terhadap penghindaran pajak. Untuk memaksimumkan kompensasi yang aan diterima manajemen akan semakin terdorong untuk melakukan penghematan termasuk penghematan pajak. Oleh karena itu hipotesis ke tujuh yang dikembangkan dalam penelitian ini adalah:

H7 Semakin besar kompensasi manajemen semakin tinggi penghindaran pajak

\section{Rerangka Penelitian}

Berdasarkan kajian literatur dan pengembangan 
hipotesis maka dapat digambarkan rerangka penelitian seperti pada gambar 1 berikut:

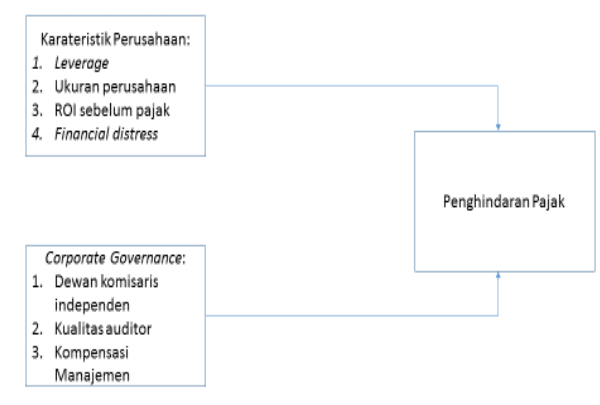

Gambar 1: Rerangka Penelitian

\section{Metode Penelitian}

Penelitian ini adalah penelitian kuantitatif yang bertujuan untuk mengeksplorasi determinan penghindaran pajak pada perusahaan public yang dikontrol keluarga. Objek penelitian adalah perusahaan publik yang dikontrol oleh keluarga yang terdaftar di BEI sampai dengan tahun 2016. Kriteria kepemilikan keluarga adalah seluruh kepemilikan individu dan perusahaan yang tercatat (kepemilikan $5 \%$ keatas wajib tercatat) kecuali perusahaan publik, negara, institusi keuangan dan kepemilikan publik yang tidak wajib tercatat (Koh, Park, dan Han, 2011). Mengacu pada Koh, Park dan Han (2011) perusahaan publik dikontrol oleh keluarga apabila jumlah kepemilikan keluarga paling sedikit 30\%.

Kriteria pemilihan sampel adalah: (1) bukan industri keuangan dan perbankan, (2) bukan industri yang mempunyai perlakuan peraturan pajak khusus (lex specialist), (3) bukan industri yang pengenaan pajaknya secara final, (4) tersedia data keuangan dan data lain secara lengkap sesuai kebutuhan analisis. Data yang digunakan adalah data sekundair berupa laporan keuangan dan annual report tahun 2014-2016 yang diperoleh dari database thomson reuter datastream dan Indonesian Capital Market Electronic Library (ICAMEL).

Model yang digunakan untuk menguji hipotesis adalah model regresi berganda dengan struktur data panel sebagai berikut:

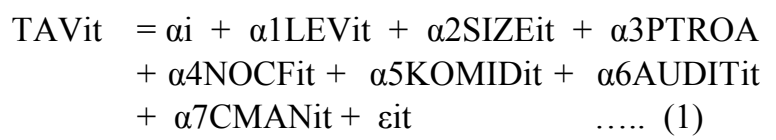

Operasionalisasi Variabel:

TAVit adalah Tax Avoidance, diukur discretionary permanent book-tax differences model Frank, Luann, Lynch dan Rego (2009) adalah: PermBTDit $=\alpha 0$ $+\alpha 1$ INTANGit $+\alpha 2$ MIit $+\alpha 3$ CSTEit $+\alpha 4 \Delta$ NOLit + $\alpha 5$ permBTD(t-1)it + cit . PermBTDit adalah permanent book-tax differences perusahaan i periode $\mathrm{t}$ yang diperoleh dari selisih antara total BTD perusahaan $\mathrm{i}$ periode $\mathrm{t}$ dikurangi temporary BTD perusahaan i periode t. Total BTD = Book Income (current tax expense/statutory tax rate), dan nilai temporary BTD $=$ deferred tax expense/statutory tax rate, INTANGit adalah nilai goodwill dan intangibel assets perusahaan i periode t, MIit adalah laba (rugi) dari minoritas, CSTit merupakan nilai beban pajak kini, $\triangle$ NOLit merupakan perubahan nilai kompensasi kerugian, permBTD(t-1)it adalah lag 1 tahun nilai beda permanen. Nondiscretionary book-tax differences merupakan fitted value persamaan dan discretionary book-tax differences adalah nilai residu atau error dari persamaan tersebut.

LEVit adalah leverage perusahaan i periode $t$ yang diukur dengan rasio antara total utang (utang jangka panjang + utang jangka pendek) terhadap total asset perusahaan i periode t. Ukuran ini telah banyak digunakan oleh peneliti terdahulu seperti: Jaggi et al. (2009), dan Moore (2012).

SIZEit adalah ukuran perusahaan i periode $\mathrm{t}$ yang diukur dengan logaritma natural nilai total aset perusahaan i periode t. Dalam kaitannya dengan kepatuhan kewajiban pajak, Hanlon et al. (2005), Desai dan Riedel (2013) menemukan bahwa ukuran perusahaan berpengaruh terhadap kepatuhan pembayaran beban pajak

PTROAit adalah tingkat pengembalian investasi sebelum pajak perusahaan i periode $t$, yang diukur dengan nilai pre-tax book income perusahaan i periode $t$ dibagi total asset pada periode $t-1$

NOCFit adalah perubahan aliran kas perusahaan i periode $\mathrm{t}$ diukur dengan nilai perubahan cash flow from operation periode $\mathrm{t}-1$ ke periode $\mathrm{t}$ diskalakan terhadap nilai asset periode $\mathrm{t}-1$, merupakan variabel 
dummy, diberi skore 1 jika NOCFit bernilai $<0$ dan 0 jika lainnya.

KOMIDit adalah komisaris independen perusahaan i periode $t$ yang diukur dengan proporsi (\%) komisaris independen terhadap jumlah komisaris.

AUDITit adalah kualitas audit perusahaan i periode $\mathrm{t}$ diukur dengan audit spesialisasi industri. Dalam penelitian ini audit spesialisasi industri diukur dengan besarnya pangsa pasar yang dikuasai oleh auditor. Nilai pangsa pasar diperoleh dari membagi total rasio penjualan terhadap asset seluruh perusahaan yang diaudit oleh KAP tertentu dibagi dengan total rasio penjualan terhadap asset keseluruhan perusahaan yang ada dalam industri tersebut, berupa variabel dummy dengan nilai 1 jika pangsa pasar auditor paling rendah $20 \%$ dan 0 untuk lainnya.

CMANit adalah kompensasi manajemen perusahaan $i$ periode $t$ yang diukur dengan rata-rata nilai kompensasi manajemen, dihitung dengan membagi total biaya kompensasi CEO dibagi jumlah CEO.

\section{Hasil dan Pembahasan}

\section{Seleksi Sampel}

Penelitian ini dilakukan pada perusahaan publik yang terdaftar di Bursa Efek Indonesia sampai dengan tahun 2016. Tahun analisis adalah tahun 2014 sampai 2016 dengan unit analisis tahun perusahaan (firm-year). Secara keseluruhan jumlah unit observasi yang menjadi objek penelitian adalah 1.582 tahun perusahaan. Setelah melalui seleksi sampel sesuai dengan kriteria yang ditentukan diperoleh sampel akhir sebanyak 336 tahun perusahaan atau $21.2 \%$ dari jumlah observasi.

\section{Statistik Deskriptif}

Tabel 1 mempresentasikan deskriptif statistik yang memberikan gambaran umum profil sampel dan variabel penelitian.

Tabel 1

Statistik deskriptif variabel penelitian

\begin{tabular}{|l|c|c|c|c|}
\hline Variabel & Max & Min & Mean & Stdev \\
\hline TAV & 0,1076 & $-0,0795$ & 0,0034 & 0,0443 \\
\hline LEV & 0,8262 & 0,1699 & 0,4859 & 0,1872 \\
\hline SIZE & 13,0201 & 0,9419 & 9,6612 & 9,0220 \\
\hline
\end{tabular}

\begin{tabular}{|l|c|c|c|c|}
\hline Variabel & Max & Min & Mean & Stdev \\
\hline PTROA & 0,175 & $-0,1131$ & 0,0441 & 0,0693 \\
\hline NOCF & 0,1596 & $-0,1557$ & 0,0017 & 0,0774 \\
\hline KOMID & 0,4069 & 0,3216 & 0,3572 & 0,0885 \\
\hline AUDIT & 1 & 0 & 0,3355 & 0,4722 \\
\hline CMAN & 0,4155 & 0,0026 & 0,1293 & 0,0765 \\
\hline N & \multicolumn{5}{|c|}{336} \\
\hline $\begin{array}{l}\text { Keterangan: } \\
\text { TAV: tax avoidance, LEV: tingkat leverage perusahaan, } \\
\text { SIZE: ukuran perusahaan, PTROA: tingkat pengembalian } \\
\text { investasi sebelum pajak NOCF: perubahan nilai arus kas } \\
\text { operasional, KOMID: proporsi dewan komisaris independen, } \\
\text { AUDITQ: kualitas audit, CMAN: kompensasi manajemen. }\end{array}$ \\
\hline
\end{tabular}

Statistik deskriptif menunjukkan bahwa nilai mean TAV adalah positif 0,0034 menunjukan bahwa secara rata-rata perusahaan sampel telah melakukan penghindaran pajak. Nilai TAV positif menggambarkan bahwa laba akuntansi lebih besar dari laba fiscal dan perbedaan tersebut dikarenakan faktor diskresi manajemen.

\section{Hasil Pengujian Hipotesis}

Secara ringkas hasil pengujian hipotesis disajikan pada tabel 2 berikut.

Tabel 2.

Hasil Analisis Regresi Multivariat Determinan Penghindaran Pajak

\begin{tabular}{|c|c|c|c|}
\hline $\begin{array}{c}\text { Variabel } \\
\text { Independen }\end{array}$ & Prediksi & Koefisien & Prob t \\
\hline Konstanta & & 0,1153 & $0,000 * * *$ \\
\hline LEV & - & $-0,3207$ & $0,042 * *$ \\
\hline SIZE & + & 0,2803 & 0,244 \\
\hline PTROA & + & 0,0132 & $0,000 * * *$ \\
\hline NOCF & + & 0,0062 & $0,014 * *$ \\
\hline KOMID & - & $-0,0008$ & 0,913 \\
\hline AUDIT & - & $-0,0086$ & $0,032 * *$ \\
\hline CMAN & + & 0,3313 & $0,009 * * *$ \\
\hline $\mathrm{N}$ & \multicolumn{3}{|c|}{336} \\
\hline $\operatorname{Adj} R^{2}$ & \multicolumn{3}{|c|}{0,3272} \\
\hline \multicolumn{4}{|c|}{$\begin{array}{l}\text { Keterangan: } \\
\text { TAV: tax avoidance, LEV: tingkat leverage } \\
\text { perusahaan, SIZE: ukuran perusahaan, PTROA: } \\
\text { tingkat pengembalian investasi sebelum pajak NOCF: } \\
\text { perubahan nilai arus kas operasional, KOMID: } \\
\text { proporsi dewan komisaris independen, AUDITQ: } \\
\text { kualitas audit, CMAN: kompensasi manajemen. }\end{array}$} \\
\hline
\end{tabular}

Hipotesis pertama (H1) menduga bahwa "semakin besar tingkat leverage perusahaan semakin rendah penghindaran pajak". Berdasarkan koefisien determinasi diperoleh hasil bahwa koefisien determinasi $-0,3207$ dan signifikan pada level $\alpha=$ 
5\%. Hasil pengujian sesuai dengan prediksi membuktikan bahwa tingkat leverage berpengaruh negative terhadap penghindaran pajak. Semakin tinggi tingkat utang perusahaan semakin rendah penghindaran pajak. Temuan ini sejalan dengan Gaham dan Tucker (2006), Koh, Park dan Han (2011), juga Moore (2012) yang telah menemukan bahwa penghindaran pajak lebih rendah pada perusahaan yang mempunyai tingkat leverage yang lebih tinggi.

Hasil penelitian ini mendukung teori penghindaran pajak berdasarkan perspektif teori struktur modal (Ross, Westerfield, dan Jordan, 2008) yang menyatakan bahwa perusahaan yang menggunakan sumber dana dari utang akan memperoleh manfaat berupa penghematan pajak dikarenakan adanya beban bunga utang. Semakin tinggi utang yang digunakan maka semakin tinggi penghematan pajak yang dinikmati sehingga perusahaan tidak lagi terdorong untuk melakukan penghindaran pajak.

Hipotesis kedua (H2) menduga bahwa "Semakin besar ukuran perusahaan semakin rendah penghindaran pajak". Penelitian ini tidak dapat membuktikan pengaruh ukuran perusahaan terhadap penghindaran pajak. Temuan ini ditunjukkan dengan tingkat signifikansi pada level $\alpha$ melampaui $10 \%$. Hasil penelitian ini tidak sejalan dengan temuan Parulian (2014) dan Warsini (2018) yang menemukan bahwa ukuran perusahaan berpengaruh positif terhadap penghindaran pajak. Hasil penelitian ini juga tidak mendukung teori political cost hypothesis (Scott, 2014). Kegagalan penelitian ini untuk membuktikan pengaruh ukuran perusahaan terhadap penghindaran pajak bisa jadi disebabkan karena kurang tepatnya pengukuran ukuran perusahaan yang menggunakan nilai logaritma natural dari nilai asset perusahaan. Nilai logaritma natural asset tidak bisa mencerminkan ukuran perusahaan yang sesungguhnya.

Hipotesis ketiga (H3) yang dikembangkan dalam penelitian ini adalah "semakin besar tingkat pengembalian investasi sebelum pajak semakin tinggi penghindaran pajak". Berdasarkan nilai koefisien determinasi dan tingkat signifikansi terbukti bahwa pengembalian investasi sebelum pajak berpengaruh positif signifikan terhadap penghindaran pajak yang ditunjukan dengan koefisien sebesar 0,0132 signifikan pada tingkat $\alpha=1 \%$. Dapat diinterpretasikan bahwa semakin besar perusahaan memperoleh pengembalian investasi sebelum pajak akan mendorong manajemen untuk melakukan penghindaran pajak yang lebih besar.

Dengan diterapkannya tarif pajak penghasilan badan pada besaran tertentu, maka besarnya pajak yang akan dibayar perusahaan akan proporsional dengan besarannya imbal hasil. Hasil penelitian ini sejalan dengan penelitian yang dilakukan oleh Frank, Luann, Lynch dan Rego (2009).

Faktor karakteristik perusahaan lainnya yang diduga berpengaruh terhadap penghindaran pajak adalah likuiditas perusahaan. Mengingat beban pajak adalah beban yang bersifat tunai maha hipotesis keempat (H4) menduga bahwa "semakin tinggi financial distress perusahaan semakin tinggi penghindaran pajak". Sesuai dengan dugaan hasil penelitian ini membuktikan bahwa kesulitan keuangan (financial distress) berpengaruh positif signifikan terhadap penghindaran pajak yang ditunjukkan dengan koefisien determinan positif sebesar 0,0062 dan signifikan pada level $\alpha=5 \%$. Hasil penelitian ini sejalan dengan Frank, Luann, Lynch dan Rego (2009) yang menyatakan bahwa perusahaan yang mengalami kesulitan keuangan cenderung melakukan upaya penghindaran pajak.

Seperti diketahui bahwa penghindaran pajak merupakan diskresi manajemen, oleh karena itu penghindaran pajak tentu saja tidak terlepas lingkungan perusahaan yang tercermin dalam tata kelola perusahaan. Pengujian selanjutnya dilakukan untuk membuktikan pengaruh tata kelola perusahaan terhadap penghindaran pajak.

Hipotesis kelima (H5) menduga bahwa "semakin besar proporsi dewan komisaris independen semakin rendah penghindaran pajak". Hasil pengujian menunjukkan bahwa tingkat signifikansi koefisien determinasi untuk variabel KOMID berada pada level $\alpha$ melampaui 10\%. Dapat dikatakan bahwa proporsi dewan komisaris independen tidak signifikan mempengaruhi penghindaran pajak. Hasil ini tidak sejalan dengan Lanis dan Richardson (2011), namun konsisten dengan temuan Minnick dan Noga (2010).

Kegagalan membuktikan pengaruh dewan komisaris independen ini sejalan dengan berbagai penelitian berkaitan dengan manajemen laba di Indonesia juga tidak mampu menemukan bukti adanya pengaruh signifikan dewan komisaris independen (Siregar, 2005; Siregar dan Utama, 
2008). Bisa jadi penggunaan ukuran proporsi atau persentase jumlah dewan komisaris independen tidak tepat untuk mengukur efektifitas pengawasan dikarenakan proporsi dewan komisaris independen pada perusahaan public di Indonesia berkisar dari $30 \%$ hingga $40 \%$. Proporsi ini sesuai dengan ketentuan dari regulator yang mengharuskan jumlah dewan komisaris independen untuk perusahaan public di Indonesia minimal 1/3 dari keseluruhan dewan komisaris. Oleh karena itu proporsi dewan komisaris independen kurang bisa mencerminkan efektifitas pengawasan kepada kebijakan manajemen.

Variabel tata kelola lainnya yang dipertimbangkan dalam penelitian ini adalah kualitas auditor. Hipotesis keenam (H6) yang dikembangkan menduga bahwa "penghindaran pajak lebih rendah pada perusahaan yang diaudit oleh auditor eksternal yang berkualitas". Dengan menggunakan ukuran audit spesialisasi industri, penelitian ini mampu membuktikan adanya pengaruh negative kualita $\mathrm{s}$ audit terhadap penghindaran pajak. Temuan ini ditunjukkan dengan signifikansi koefisien determinan sebesar $-0,0086$ (negative) dan signifikan pada level $\alpha=5 \%$. Hasil penelitian ini sejalan dengan Noh, Doocheol dan Guiral (2014), juga Kanagaretnam, Lee dan Lim (2016).

Menurut Noh, Doocheol dan Guiral (2014) auditor yang mempunyai spesialisasi industry mempunyai pemahamam yang lebih besar terhadap seluk beluk permasalahan klien termasuk masalah perpajakan. Laporan keuangan auditan juga merupakan tanggung jawab auditor. Tindakan penghindaran pajak sangat memungkinkan membawa risiko reputasi buruk apabila ditemukan dan menjadi sengketa antara wajib pajak dengan apparat pajak. Oleh karena itu auditor yang berkualitas atau bereputasi enggan untuk menanggung risiko reputasi tersebut.

Hipotesis ketujuh (H7) menduga bahwa "semakin besar kompensasi manajemen semakin tinggi penghindaran pajak". Penelitian ini mampu membuktikan bahwa kompensasi manajemen berpengaruh positif terhadap penghindaran pajak, yang ditunjukkan dengan koefisien determinan sebesar 0,3313 dengan signifikan pada level $\alpha=1 \%$.
Temuan ini dapat diinterpretasikan bahwa semakin tinggi kompensasi yang diterima oleh manajeman maka manajemen akan berusaha untuk mempertahankan bahkan meningkatkan kompensasi yang akan diterima. Pada umumnya kompensasi manajemen ditetapkan berdasarkan laba sesudah pajak, oleh karena itu kompensasi yang tinggi dapat diwujudkan apabila perusahaan mampu melakukan penghematan seperti penghematan pajak sehingga diperoleh laba sesudah pajak yang semakin besar. Hasil penelitian ini sejalan dengan penelitian terdahulu yang dilakukan oleh Hanlon, Mills dan Slemrod (2005) dan Gaertner (2014).

\section{Kesimpulan}

Berdasarkan nilai rata-rata variabel penghindaran pajak adalah positif dapat disimpulkan bahwa perusahaan public yang dikontrol oleh keluarga terbukti telah melakukan tindakan penghindaran pajak baik secara legal maupun illegal. Penghindaran pajak tersebut dipengaruhi oleh faktor karakteristik perusahaan yaitu: semakin besar tingkat utang sebagai sumber pendanaan perusahaan mampu menurunkan tindakan penghindaran pajak, namun semakin besar pengembalian investasi sesudah pajak dan semakin besar kesulitan keuangan akan mendorong perusahaan melakukan penghindaran pajak. Selain karateristik perusahaan, penghindaran pajak juga dipengaruhi oleh mekanisme corporate governance. Penerapan good corporate governance seperti adanya pengawasan dari auditor yang berkualitas mampu menekan tindakan penghindran pajak, akan tetapi pemberian kompensasi manajemen yang semakin besar justru mendorong tindakan penghindaran pajak.

\section{REFERENSI}

Atwood, T.J., Drake, M. S., Myers, J.N., dan Myers, L. A. (2012) Home Country Tax System Characteristics and Corporate Tax Avoidance: International Evidence. The Accounting Review, 87, 1831-1860

Becker Bo, Marcus Jacob dan Martin Jacob, (2013). Payout Taxes and The Allocation of Investment, Journal of Finance Economics, 107: $1-24$ 
Bena, Jan, dan Hanousek, (2008). Rent Extraction by Large Shareholders: Evidence Using Dividend Policy in the Czech Republic, Journal of Economics and Finance, 58: 106-130

Chen, S., Chen, X., Cheng, Q., dan Shevlin, T. (2010). Are Family More tax Aggressive than Non-Family Firms?. Journal of Financial Economics, 95, 41-61

Claessens, S., S.Dajnkov dan Larry H.P.Lang, (2000). The Separation of Ownership in East Asia Corporation, Journal of Finance Economics, 58: 81-112

Darussalam, John Hutagaol dan Danny Septriadi, (2010). Konsep dan Aplikasi Perpajakan Internasional, Danny-Darussalam Tax Center, Jakarta

Dharmapala. D. dan Nadine Riedel, (2013). Earnings Shocks and Tax-Motivated Income Shifting : Evidence from European Multinationals, Journal of Public Economics, 97: 95-107

Desai A. Mihir dan Dhammika Dharmapala, (2007). Taxation and Corporate Governance: An Economic Approach, the Conference on Taxation and Corporate Governance at the Max Planck Intitute in Munich,SSRN, diunduh Juni 2015, 1-23

Dyreng, S.D., Hanlon, M. dan Maydew, E.L., (2010). Long-Run Corporate Tax Avoidance, The Accounting Review, 83: 61-82.

Frank, M.M, Lynch, L., J. dan Rego, S., O. (2009). Tax Reporting Aggressiveness and Its Relation to Aggressive Financial reporting. The Accounting Review, 84, 467-496

Gaertner, F., (2014), CEO After Tax Compensation Intencives and Corporate Tax Avoidance. Contemporary Accounting Research, 431

Garbarino, Carlo, (2007). Aggressive Tax Strategies and Corporate Tax Governance: An Institutional Approach, Working paper, http://ssrn.com.case no.188/08, diunduh Juni 2013, 1-17

Graham J. R. dan Alan L. Tucker, (2006). Tax Shelter and Corporate Debt Policy, Journal of Financial Economics, 81: 563594

Hanazaki, Masaharu dan Qun Liu, (2007). Corporate Governance and Investment in East Asian firms: Empirical Analysis of Family Controlled firms, Journal of Asian Ecocnomics, 18: 76-97

Hanlon, Michelle, Gopal V.Krishnan, dan Lillian F. Mills, (2012). Audit Fee and Book-Tax Differences, Journal of the American TaxationAssociation, 34: 55-86

Hanlon, M., Edward L. Maydew dan Terry Shevlin, (2008). An Unintended Consequence of Book-Tax Conformity : A Loss of Earnings Informativeness, Journal of Accounting and Economics, $46: 294-311$

Jaggi, Bikki, Sidney Leung dan Ferdinan Gul, (2009). Family Control, Board Independence and Earnings Management: Evidence based on Hong Kong firms, Journal of Accounting and Public Policy, 28: 281-300
Jensen, M. dan Meckling, W, (1976). Theory of The Firm: Managerial Behavior, Agency Costs and Ownership Structure, Journal of Finance Economics, 3: 305-360.

Jiang, H., Habib, A. dan Hu, B. (2011). Ownership Concentration, Voluntary Disclosures and Information Asymmetry in New Zealand. The British Accounting Review, 43, 39-53

Kanagaretnam, K., Lee, J., Lim, C. Y., dan Lobo, G. (2016) Relation between Auditor Quality and Tax Aggressiveness: Implications of Cross-Country Institutional Differences, Auditing A Journal of Practice \& Theory, 35: 105-135

Khan, Mozaffar, Srinivasan, Suraj dan Tan, Liang (2016), Institutional ownership and corporate tax avoidance: New evidence, The Accounting Review, 92-2: 101-122

Koh, S.,Y., Park, S., Y., dan Han, J., S. (2011). Conformity between the Book Income \& Taxable Income of Family Firms, and its Value Relevance: Empirical Evidence from Korea. the $12^{\text {th }}$ Asian Academic Accounting Association, Bali-Indonesia, 1-29

Lanis, Roman dan Grant Richardson, (2011). The effect of Board of Director Composition on Corporate Tax Aggressiveness, Journal of Accounting and Public Policy, 30: 50-70

Lim, Youngdeok, (2011). Tax Avoidance, Cost of debt and Shareholder activism : Evidence from Korea, Journal of Banking and Finance, 35: 456-470

Mafrolla, E., dan D’Amico, Eugenio, (2016). Tax Aggressiveness in Family Firms and the Non-linear Entrenchment Effect, Journal of Family Business Strategy, 7: 178-184

Masripah, M., Diyanty, Vera, dan Fitriasari, Debby, (2016) Controlling Shareholder and Tax Avoidance: Family Ownership and Corporate Governance, International Research Journal of Business Studies, 8: 3-32

Maydew, E., dan D. Shackelford, (2006). The Changing Role of Auditors in Corporate Tax Planning, Taxing Corporate Income in the 21th century, Cambridge University, diunduh Juni 2015, 1-23

Mc.Guire, S. T. Omer, dan D. Wang, (2012). Tax Avoidance: Do Industry Experts Make a Difference?, The Accounting Review, 87: 975-1003

Mills, L. dan Newberry K., (2001). The Influence of Tax and Nontax cost on book-tax Reporting Differences : Public and private Firms, Journal of the American Taxation Association, 23: 1-19

Minnick, Kristina dan Tracy Noga, (2010). Do Corporate Governance Characteristics Influence Tax management?, Journal of Corporate Finance, 16: 703-718

Moore, Jared A., (2012). Empirical Evidence on the Impact of External Monitoring on Book-Tax Differences, Advances in Accounting, Incorporating Advances in International Accounting, $\mathrm{xxx}$ (article in press): $\mathrm{xxx}-\mathrm{xxx}$

Noh, Doocheol, dan Andres Guiral, (2014). The Effect of AuditorProvided Tax Services on Tax and 
Financial Reporting Aggressiveness, Advanced Science and Technology Letters, 47: 89-92

Parulian, S.R., (2014)., Ananlisis faktor faktor yang mempengaruhi Tax Avoidance dan Pengaruh Tax avoidance terhadap Nilai Perusahaan, Disertasi Universitas Indonesia

Richardson, Grant, Roman Lanis dan Sidney Chi Moon Leung, (2014). Corporate Tax Aggressiveness, Outside Directors, and Debt Policy: An Empirical Analysis, Journal of Corporate Finance, 25: 107-121

Ross, W. Ryan, Westerfield dan Jordan, (2008). Corporate Finance Fundamentals $8^{\text {th }}$ edition, New York, McGraw-Hill

Scott, W., R. (2014). Financial Accounting Theory, seven edition, Prentice-Hall, Canada

Siregar, S. Veronica dan S. Utama (2008) Type of Earnings Management and the Effetc of Ownership Strukture, Firm Size and
Corporate Governance Practice: Evidence from Indonesia, The International Journal of Accounting, 43: 1-27

Siregar, Sylvia Veronica, (2005). Pengaruh Struktur Kepemilikan, Ukuran Perusahaan dan Praktek Corporate Governance terhadap Earnings Management dan Kekeliruan Penilaian Pasar, Disertasi, PascaSarjana FEUI

Taylor Grantley dan Grant Richardson, (2012). International Corporate Tax Avoidance Practices : Evidence from Australian Firms, The International Journal of Accounting, 47: 469-496

Warsini, Sabar, (2018). The Effect of Family Ownership on the Relationship between Aggressive Financial and Tax Reporting: Evidence from 10 Asian Countries, Proceeding Asia Pacific Business and Economics Conference, Universitas Indonesia 17-18 Januari 2018

................., The Global Competitiveness Report, World Economics Forum, 2017 